\title{
Neonatal Fc Receptor: From Immunity to Therapeutics
}

\author{
Timothy T. Kuo • Kristi Baker • Masaru Yoshida • \\ Shuo-Wang Qiao • Victoria G. Aveson • \\ Wayne I. Lencer $\cdot$ Richard S. Blumberg
}

Received: 10 September 2010 / Accepted: 14 September 2010/Published online: 1 October 2010

(C) The Author(s) 2010. This article is published with open access at Springerlink.com

\begin{abstract}
The neonatal Fc receptor ( $\mathrm{FcRn}$ ), also known as the Brambell receptor and encoded by Fcgrt, is a MHC class I like molecule that functions to protect $\operatorname{IgG}$ and albumin from catabolism, mediates transport of $\operatorname{IgG}$ across epithelial cells, and is involved in antigen presentation by professional antigen presenting cells. Its function is evident in early life in the transport of $\operatorname{IgG}$ from mother to fetus and neonate for passive immunity and later in the development of adaptive immunity and other functions throughout life. The unique ability of this receptor to prolong the half-life of IgG and albumin has guided engineering of novel therapeutics. Here, we aim to summarize the basic understanding of FcRn biology, its functions in various organs, and the therapeutic design of antibody- and albumin-based therapeutics in light of their interactions with FcRn.
\end{abstract}

T. T. Kuo $(\bowtie) \cdot$ K. Baker $\cdot$ V. G. Aveson $\cdot$ R. S. Blumberg Division of Gastroenterology, Department of Medicine, Brigham \& Women's Hospital, Harvard Medical School, 75 Francis St., Boston, MA 02115, USA

e-mail: ttkuo@partners.org

\section{Yoshida}

Department of Gastroenterology \& The Integrated Center for Mass Spectrometry,

Kobe University Graduate School of Medicine,

7-5-1 Kusunoki-cho, Chuo-ku,

Kobe 650-0017, Japan

\section{S.-W. Qiao}

Institute of Immunology, Rikshospitalet, University of Oslo, Oslo, Norway

W. I. Lencer

Gastroenterology Division, Children's Hospital,

Harvard Digestive Disease Center, Harvard Medical School,

Boston, MA 02115, USA
Keywords FcRn $\cdot$ Fcgrt $\cdot$ Brambell $\cdot \mathrm{IgG} \cdot \mathrm{Fc} \cdot$ albumin . transcytosis $\cdot$ transport $\cdot$ recycling

\section{Introduction}

Decades before the identification of neonatal Fc receptor $(\mathrm{FcRn})$ as the receptor that transports IgG from mother to offspring, early experiments revealed passive transfer of immunity via gamma-globulin. Francis William Rogers Brambell (1901-1970) was an Irish-born zoology professor who made significant contributions to these observations and subsequently hypothesized the existence of a receptor that can mediate the transfer of maternal gamma-globulin from mother to infant as well as the protection of gammaglobulin from catabolism [1,2]. Later studies by Richard Rodewald's group provided biochemical evidence of IgG transport at the neonatal rat intestinal epithelium with $\mathrm{pH}$ binding dependency [3]. This finally led Neil Simister and Keith Mostov to purify and sequence a Fc receptor from the intestine of an 11-day-old rat (hence the name neonatal $\mathrm{Fc}$ receptor) that was associated with beta ( $\beta$ )-2-microglobulin and exhibited structural similarity to MHC class I molecules [4].

\section{FcRn Structure and Ligand Binding Characteristics}

Similar to MHC class I, FcRn structure consists of three extracellular alpha $(\alpha)$ domains, a single pass transmembrane domain, and a short cytoplasmic tail of approximately 44 amino acids. Crystal structural resolution by Pam Bjorkman's group, who had previously resolved the crystal structure for MHC I, showed that the $\alpha 1$ and $\alpha 2$ domain 
perch on top of the $\alpha 3$ domain and $\beta 2 \mathrm{~m}$. The two sites where peptide termini anchors in MHC class I are blocked in FcRn by an arginine side chain and another by a proline residue in the $\alpha 2$ helix region [5]. Two FcRn molecules bind to a single $\operatorname{IgG}$ with a $2: 1$ stoichiometry, and the binding occurs at $\mathrm{pH}$ 6.0-6.5 with minimal structural conformation change and not at $\mathrm{pH} 7.5[5,6]$. The critical binding site at acid $\mathrm{pH}$ in the $\operatorname{IgG} \mathrm{Fc}$ domain resides within a pair of histidines that occur in the $\alpha 3$ domain [7]. Rat FcRn and IgG binding studies have shown that the FcRn contact sites for IgG involve Aspartic acid 137 , an $\mathrm{N}$-glycan moiety within the $\alpha 2$ domain, and the $\mathrm{N}$ terminus of $\beta 2 \mathrm{~m}$ [8].

The observation that staphylococcal protein A blocks FcRn and $\mathrm{IgG}$ binding helped to identify the $\mathrm{CH} 2-\mathrm{CH} 3$ domain interface as a critical site of FcRn-IgG interactions. Site-directed mutagenesis studies have proven that the critical binding sites in the $\mathrm{Fc}$ domain of $\mathrm{IgG}$ for $\mathrm{FcRn}$ are Histidine 310, Histidine 435, and Isoleucine 253 and to a lesser extent Histidine 433 and Tyrosine 436 [9, 10]. At acid $\mathrm{pH}$, the protonated histidine residues on IgG form a salt bridge with the FcRn $\alpha 2$ domain at Glutamic acid 117, Glutamic acid 132, and/or Glutamic acid 135 and Aspartic acid 137.

\section{Binding Site of Albumin}

Although a putative albumin receptor was also hypothesized by Schultze and Heremans in 1966, it was not until 2003 when Clark Andersen's group demonstrated a biochemical association between FcRn and albumin [11, 12]. FcRn also protects albumin from catabolism and thus in humans the endogenous albumin half-life is approximately 19 days, while in rodents, it is $1.5-2.5$ days. FcRn in the liver is the critical site that maintains albumin concentration homeostasis by producing the same quantity as is degraded systemically [13]. FcRn binds albumin with a 1:1 stoichiometry. Similar to the $\mathrm{pH}$ dependency of FcRn-IgG interactions, FcRn and albumin also bind together at acidic $\mathrm{pH}$ but not at neutral $\mathrm{pH}$. The contact site of FcRn also involves a histidine residue (H166) within the $\alpha 3$ domain but located on the opposite structural face of FcRn from that which is involved in contacting $\operatorname{IgG}[14,15]$. The FcRn contact site on albumin resides somewhere within the last third of its three major structural domains. It is still not known whether a single FcRn can simultaneously bind and transport both $\operatorname{IgG}$ and albumin in physiologic conditions. Also, the crystal structure FcRn bound to albumin has yet to be resolved. Nonetheless, genetic deficiency of FcRn in genetically engineered animal models has clearly shown that such mice are both hypoalbuminemic and hypogammaglobulinemic $[13,16]$.

\section{FcRn Structural Comparisons Between Species}

The rat and mouse FcRn peptide sequences are 98\% identical and are encoded in chromosome 7, outside the MHC class I locus in chromosome 20 and 17, for rat and mouse, respectively. Human FcRn shares only $65 \%$ amino acid sequence similarity with rat FcRn. Human FcRn is encoded in chromosome 19, also outside of the MHC class I locus on chromosome 6 . The molecular weight of human (h) FcRn is approximately $42-44 \mathrm{kDa}$ with a single $\mathrm{N}$ glycan moiety, as opposed to rat FcRn which has three additional $\mathrm{N}$-glycans that account for its molecular weight of $48-52 \mathrm{kDa}$. This structural dissimilarity may explain the absence of $\mathrm{hFcRn}$ dimer formation, in the absence of $\mathrm{IgG}$, in crystal structure studies. Perhaps it is the lack of the additional $\mathrm{N}$-glycan moieties within the $\alpha 2$ domain that participate in the formation of dimer stability through a "carbohydrate handshake" as shown by X-ray crystallographic studies [17]. Another major difference between human and rodent FcRn involves the cross-species $\operatorname{IgG}$ binding. Rodent FcRn is known to be "promiscuous" in its ability to bind various species of $\mathrm{IgG}$, while $\mathrm{hFcRn}$ can only bind to a limited species (human, rabbit, and bovine) [18]. "Murinizaton" by site-directed mutagenesis of hFcRn at residues 137 and $121-132$ within the $\alpha 2$ domain was shown to allow binding to mouse $\operatorname{IgG}$, thus helping to explain this cross-species IgG binding capability of rodent FcRn [19]. Although one of the N-glycans resides within the above-mutated site, it probably does not contribute to cross-species IgG binding, since "rodentization" of $\mathrm{hFcRn}$ by addition of $\mathrm{N}$-glycans through site-directed mutagenesis failed to enhance binding to rodent IgG [20]. Although $\mathrm{hFcRn}$ cannot bind rodent IgG, recent findings have shown that $\mathrm{hFcRn}$ can bind rodent albumin, but rodent FcRn cannot bind human albumin [21]. Thus, the half-life of human albumin in rat is only $15 \mathrm{~h}$ [22].

FcRn has also been cloned from other species, such as cow, possum, sheep, water buffalo, and camel [23]. The major structural similarities between possum, sheep, and cow include a single $\mathrm{N}$-glycan moiety and a cytoplasmic tail that is ten amino acids shorter than that of the rodent counterpart. To date, cross-species FcRn- $\beta 2 \mathrm{~m}$ binding has been suggested to occur with bovine FcRn and mouse $\beta 2 \mathrm{~m}$ when the bovine $\mathrm{FcRn}$ transgene was expressed in mice and was found to be functional [24].

\section{Intracellular Trafficking of FcRn}

$\beta 2 \mathrm{~m}$ association with $\mathrm{FcRn}$ is required for proper folding of FcRn before exiting the endoplasmic reticulum (ER), and failure of such an association results in the formation of disulfide-bonded oligomers that accumulate in the ER [25]. 
Efficient intracellular trafficking, including $\operatorname{IgG}$ transport, also requires association with $\beta 2 \mathrm{~m}$ [26]. Prior to binding with $\beta 2 \mathrm{~m}$, FcRn assembly involves association with calnexin and subsequently ERp57 which assist in the formation of the disulfide bond [27]. Calreticulin is also involved in the maturation of the FcRn $-\beta 2 \mathrm{~m}$ complex in the ER [27].

FcRn expression in many different polarized epithelia in vitro systems that model the kidney, lung, placenta, and intestines has shown that FcRn expression endows upon the cell the ability to transcytose IgG bidirectionally [26, 2831]. The uptake of $\mathrm{IgG}$ by $\mathrm{FcRn}$ requires an acid environment that can occur within the intestinal lumen especially during neonatal life or in acidified endosomes. In the neonatal rat proximal intestine, a luminal $\mathrm{pH}$ of $6.0-6.5$ favors FcRn binding to $\operatorname{IgG}$ in milk for apical uptake and subsequent endocytosis and transcytosis to the contralateral basal surface where the $\mathrm{pH}$ of the circulation is approximately 7.5 which allows ligand dissociation. In the absence of an acidic $\mathrm{pH}$, IgG uptake likely occurs by fluid-phase pinocytosis and subsequent binding to FcRn after acidification of the endosome. Whether FcRn undergoes recycling or transcytosis is still under active investigation. It is known that transcytosis involves actin motor myosin $\mathrm{Vb}$ and GTPase Rab25. Rab11a has also been found to be dispensible for transcytosis but regulates basolateral membrane recycling [32]. Exocytosis involves Rab11 which is important for endosomal fusion with the plasma membrane [33]. Recent electron microscopy of FcRn trafficking in rat intestine has revealed that both endocytic and exocytic processes are associated with clathrin [34].

Regulation of intracellular trafficking in polarized epithelial cells has mostly been studied using kidney cell lines, such as MDCK or IMCD cells, which are grown as monolayers on the transwell system. As mentioned previously, $\beta 2 \mathrm{~m}$ association is critical to effective function of FcRn [26]. The cytoplasmic tail has been demonstrated by several studies to play a critical role in basolateral membrane targeting, as well as endocytosis and transcytosis. hFcRn without a cytoplasmic tail or one that contains mutations in the calmodulin binding site results in redistribution of $\mathrm{hFcRn}$ from the basolateral to the apical surface and reduced IgG transport $[35,36]$. rFcRn without the cytoplasmic tail or with a point mutation at the phosphorylation site serine-313 results in decreased apical-to-basolateral $\mathrm{IgG}$ transport [37]. Mutation of the tryptophan and dileucine motif in the cytoplasmic tail also results in increased apical membrane expression [38]. When the rFcRn cytoplasmic tail was attached to the Fc $\gamma$ RII receptor, this mutant receptor could transcytose across MDCK cells in both directions [39]. The regulation of apical membrane targeting likely involves N-glycans. In a study where hFcRn was "rodentized" by expression of additional N-glycans to resemble that of $\mathrm{rFcRn}$, the mutant $\mathrm{hFcRn}$ redistributed to the apical membrane, similar to that of wild-type $\mathrm{rFcRn}$. The mutant $\mathrm{hFcRn}$ containing additional N-glycans also reversed the direction of predominant IgG transport to an apical-to-basolateral direction similar to that of wild-type rFcRn [20].

The pathway of FcRn trafficking is also determined by the valency of the ligand. In dendritic cells, FcRn bound to large multimeric immune complexes is routed to a LAMP1 ${ }^{+}$ compartment while monomeric IgG is recycled back to the cell surface [40]. This is believed to facilitate antigen processing before antigen presentation in dendritic cells which are known to express FcRn [41]. In another study, wild-type Fc with two FcRn-binding sites was more efficiently transported and less likely to be destined for lysosomal degradation than mutant Fc with a single FcRnbinding site [42].

\section{Regulation of FcRn Expression}

Studies of the promoter regions (comparing neonatal intestinal epithelium and NIH 3T3 cells) have shown that different transcription factors can regulate the expression of FcRn at different developmental stages and tissue types consistent with the well-known developmental regulation of FcRn in rodent intestinal epithelia [43]. Upregulation of FcRn expression in intestinal epithelial cells, macrophagelike THP-1, and primary human monocytes can be induced by TNF- $\alpha$ and IL- $1 \beta$, which are known to be elevated during inflammation [44]. Conversely, INF- $\gamma$ was found to down-regulate FcRn expression [45].

FcRn expression in the neonatal intestinal epithelium of rat can also be subjected to hormonal control, and thus may explain the exceedingly high expression levels through early life. Cortisol and thyroxine can suppress FcRn expression in neonatal rat intestinal epithelium as well as inhibit IgG binding [46, 47]. Meanwhile, a different study showed that dexamethasone stimulation decreases FcRn mRNA in rat alveolar epithelial cells [31].

\section{Intestinal Expression and Function of FcRn}

FcRn expression in rat intestine is only detectable up to 19 days after birth, which coincides with weaning, and the level of expression decreases distal to the proximal duodenum. The acid $\mathrm{pH}$ at the proximal duodenum likely facilitates the uptake of IgG. Recent studies by Bjorkman and colleagues have tracked the intracellular pathways associated with individual nanogold-labeled Fc after uptake from the neonatal rat intestinal lumen and have shown the existence of a complex network of 
tubules and vesicles that exit the basolateral membrane through clathrin-coated pits as important to intracellular pathway of transcytosis [34].

Although the expression of FcRn in the intestine of adult mice is nearly undetectable, induction has been observed upon intraperitoneal immunization with Cry1Ac protoxin from Bacillus thurigiensis but at levels less than that typically observed during neonatal life [48]. This is consistent with an increasing body of data on an important functional role of FcRn in intestinal epithelia during adult life (Table I).

In humans, FcRn is detected in both fetal and adult intestines and can mediate bidirectional transcytosis across the intestinal epithelium both in vitro and in vivo [28, 49-51]. FcRn in the intestine and other mucosal tissues therefore continues to play a significant role beyond the neonatal period, especially in immune surveillance and adaptive immunity. Using mice that were humanized to express human FcRn under the control of its endogenous promoter and $\beta 2 \mathrm{~m}$ as transgenes within intestinal epithelial cells, FcRn at the intestinal epithelium was found to deliver IgG to the luminal surface where it bound to a cognate antigen before returning the complex back to the lamina propria for processing and presentation by dendritic cells to $\mathrm{CD} 4^{+} \mathrm{T}$ cells [51]. In a murine model of intestinal infection using Citrobacter rodentium, which only infects intestinal epithelial cells and is dependent upon IgG for eradication, FcRn within the intestinal epithelium was shown to be essential in directing $C$. rodentium-associated antigens within the epithelium to regional lymph nodes for initiation of an adaptive immune response [52, 53]. In the absence of FcRn, $C$. rodentium elimination was slowed. These observations also help to explain the role of the high levels of antibacterial IgG that are observed within intestinal tissues and the lumen in inflammatory bowel disease (IBD). Using a murine model of colitis, antibacterial IgG was shown to drive colitis and was dependent upon FcRn expression in antigen presenting cells [54]. These studies thus show an important role for FcRn in mediating IgG-dependent anti-infective immunity and potentially autoimmunity in immune-mediated disorders such as IBD. Such observations have important implications for adaptive immunity in general.

\section{Expression and Function of FcRn in Mammary Gland}

The mammary gland expresses various Ig receptors, including FcRn, pIgR, and CD23, for the transport of $\mathrm{IgG}, \operatorname{IgA}$, and $\operatorname{IgE}$, respectively. In sheep, the major concentrations of Ig in colostrum in descending order are IgG1, IgA, IgE, IgM, and IgG2. In milk, the concentrations in descending order are $\operatorname{IgA}, \operatorname{IgM}, \operatorname{IgE}, \operatorname{IgG} 1$, and $\operatorname{IgG} 2$ [55]. The concentration of $\mathrm{IgG}$ in human colostrum is $1 \mathrm{~g} / \mathrm{L}$, while milk only contains $50 \mathrm{mg} / \mathrm{L}$. On the other hand, the $\operatorname{IgA}$ concentration in human milk is $32 \mathrm{~g} / \mathrm{L}$.

FcRn has been found to be expressed in the mammary gland of human, mouse, cow, brushtail possum, sheep, swine, and camel [23]. In humans, FcRn is detected in the mammary gland endothelial cells rather than the epithelial cells [56]. In camels and water buffalo, immunohistochemistry has demonstrated labeling within the acini and ducts $[57,58]$. FcRn is also detected in tumor tissues such as ductal, lobular, and medullary carcinoma, as well as metastatic epithelial cells in the lymph node [56]. It is also detected in the histiocytes residing within the interstitium in association with breast cancer.

It is believed that FcRn in the mammary gland likely recycles $\operatorname{IgG}$ (to retain $\operatorname{IgG}$ in circulation) rather than promoting transport from circulation to milk. In normal lactating mice, the concentration of $\operatorname{IgG}$ in milk is less than that of serum. In $\beta 2 \mathrm{~m}$-deficient mice, the concentration of $\operatorname{IgG}$ in milk was observed to be 20 -fold less than that of serum [59]. Studies comparing transfer of $\mathrm{Fc}$ fragments and IgG with different affinities to FcRn revealed an inverse relationship between binding affinity and concentration in milk [60]. When a bovine FcRn transgene was expressed in the mammary gland of mouse, there was no increase in the milk of the infused mouse or bovine IgG which is consistent with this notion [24].

The expression levels of FcRn in the mammary gland can shift during lactation [61]. In cow and sheep, there appears to be a shift in the expression of FcRn to the apical membrane location after parturition $[62,63]$.

The clinical benefit of the long-observed transfer of passive immunity has recently been demonstrated using a murine model of asthma in which the transfer of maternal IgG1 from milk to the infant was shown to prevent allergen-specific airway disease [64-66]. Complete protection of offspring from antigen-specific allergic airway inflammation was observed.

\section{Expression and Function of FcRn in Placenta}

The transfer of passive immunity is predominantly postnatal in rodent but in utero during gestation in humans and rabbits [67]. In humans, maternal IgG in the fetal circulation increases from the early second trimester to term. IgG1 and IgG4 have found to be most efficiently transport, while IgG2 is the least. The transfer of $\operatorname{IgG}$ is believed to be due to FcRn in the human syncytiotrophoblast and the fetal intestine [49, 68]. In mouse, FcRn is expressed in the mouse yolk sac endoderm but not the chorioallantoic placenta, and it is likely the sole $\operatorname{IgG}$ transporter from mother to fetus [69]. Using BeWo cells (a human trophoblast-derived cell line that expresses FcRn) 


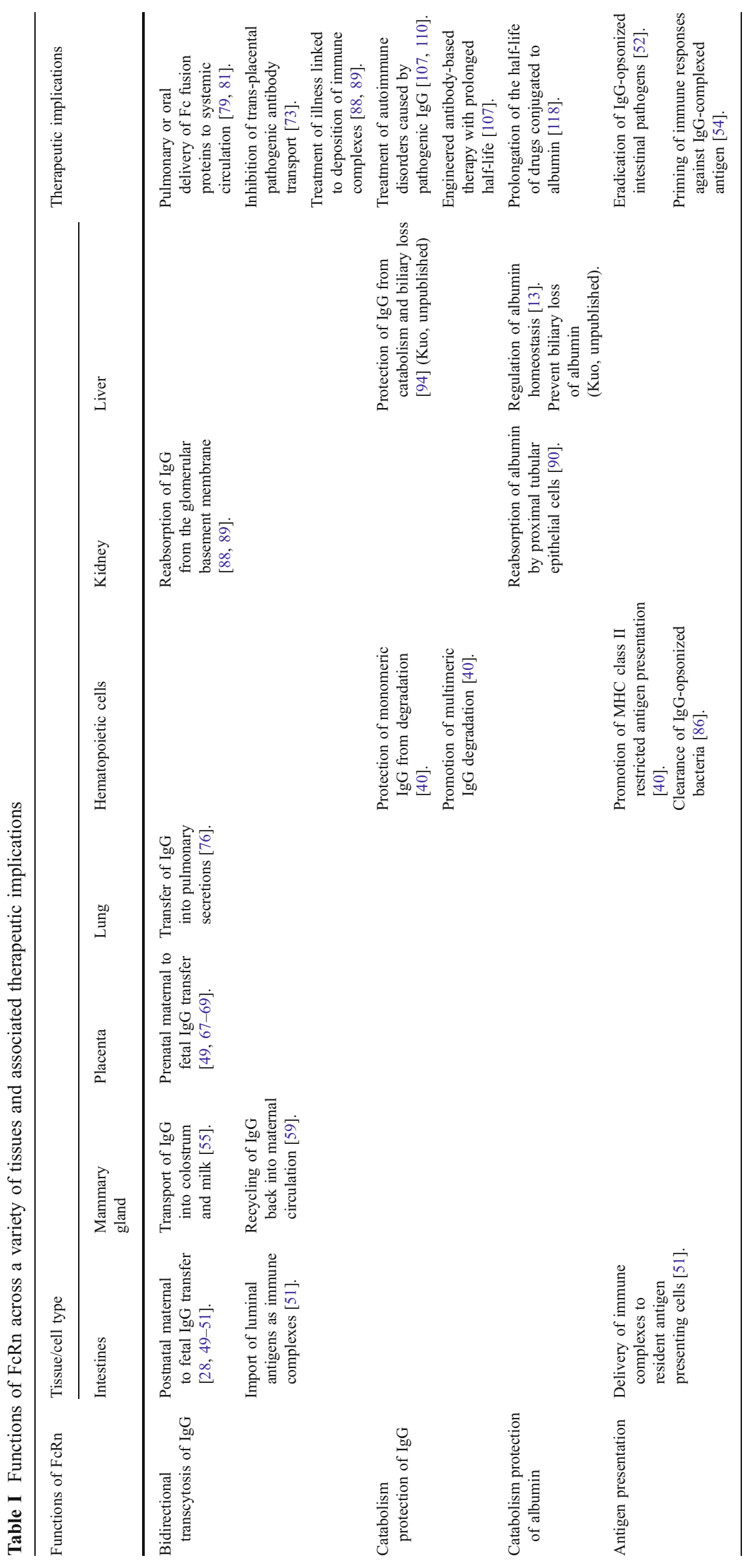


and primary placental endothelial cells, bidirectional transport and recycling of IgG have been observed [29, 70].

Although FcyRIIb is expressed in the human placental villous endothelium and yolk sac vasculature and previously believed to also transport IgG across the villous endothelium, recent studies comparing Fc $\gamma$ RIIb-deficient mice and wild-type mice have revealed that Fc $\gamma$ RIIb does not mediate IgG transport in the mouse yolk sac [71].

Placental transfer of IgG from mother to fetus can also be used to transport therapeutic recombinant $\mathrm{Fc}$ fusion proteins in utero. When a $\beta$-glucuronidase (GUS)-Fc fusion protein was infused into the pregnant mouse in a murine model of GUS deficiency, the offsprings were found to have reduced manifestation of excessive lysosomal storage in the involved organs [72]. Conversely, potentially pathogenic antibodies may also be transferred via the placenta. In a murine model of fetal and neonatal immune thrombocytopenia (FNIT), where the transfer of pathogenic maternal antibody results in the destruction of fetal/neonate platelets, FcRn was found to be critical for this pathologic condition to occur [73]. The transport of the pathogenic IgG was likely facilitated by placental FcRn, since treatment with an anti-FcRn antibody or intravenous immunoglobulin (IVIg) was found to prevent FNIT. Other than pathogenic antibodies, teratogens or peptide inhibitors of FcRn can also block the transport of $\operatorname{IgG}$ in the placenta, leading to placental necrosis and/or disruption of embryo development [74]. However, such inhibitors may serve as a method of preventing transfer of pathogenic antibodies from the maternal circulation.

\section{Expression and Function of FcRn in Lung}

FcRn expression in the lung has been exploited as an endogenous vehicle for delivery of therapeutic Fc fusion proteins and in so doing revealed the presence of physiologic transport of IgG in adult lung by FcRn [75]. FcRn is expressed by bronchial epithelial cells of adult human, non-human primate, rat, mouse, and cow, wherein it can mediate transport of IgG. Consistent with this, significant quantities of IgG can be observed in pulmonary secretions [76]. FcRn is also detected at high levels in tracheal epithelial cells [77, 78]. This likely explains the efficacy of $\mathrm{Fc}$ fusion protein delivery when inhalation is directed to the upper airways in non-human primate experiments and human clinical trials [79, 80]. Consistent with this, mutation of the FcRn-binding site within the Fc domain of the chimerized IgG fusion disables such transport [81]. Although it is not detectable in alveolar cells of humans and non-human primates, rat alveolar epithelial cell monolayer studies have demonstrated expression of FcRn at this site that can mediate bidirectional transport of IgG and with a predominant apical-to-basal direction $[31,77,81]$.

\section{Expression and Function of FcRn in Hematopoietic Cells}

FcRn has been observed to be expressed in human monocyte, macrophage, dendritic cells, splenic B cells, and monocytic cell lines such as U937 and THP-1 [41, 82]. FcRn expression levels in these cell lines has been found to be increased by exposure to CpG, LPS, and TNF- $\alpha$, and decreased with inhibition of NF-KB [44]. FcRn is also expressed in mouse hematopoietic cells, and within this cell type, it has been shown to be involved in IgG homeostasis together with endothelial cells [40, 41, 82, 83].

In dendritic cells, FcRn sorts multimeric IgG-containing immune complexes to intracellular compartments associated with antigen processing and ultimately degradation such that immune complexes exhibit diminished clearance in vivo in the absence of FcRn function [40, 84]. Consistent with this, FcRn in human and mouse dendritic cells plays a critical role in $\mathrm{MHC}$ class II-restricted antigen presentation [40]. FcRn in dendritic cells can also mediate MHC class Irestricted cross-presentation in the setting of chronic inflammation (K.B. and R.S.B. unpublished observations). Dendritic cells may also be involved in tolerance induction since oral administration of anti-CD3 antibody has been found to be effective in prevention and treatment of autoimmune diabetes and encephalomyelitis in mice [85]. In neutrophils, FcRn can facilitate the uptake of bacteria opsonized by antigen-specific IgG and deliver it to phagolysosomes [86].

\section{Expression and Function of FcRn in Kidney}

Consistent with studies of kidney cell lines, bidirectional transport of $\mathrm{IgG}$ in primary human renal proximal tubular epithelium had been observed [87]. FcRn is expressed in the podocyte and proximal tubule, but not the mesangial cell, parietal epithelial cells, interstitium, medulla, or distal tubular cells $[88,89]$. FcRn in podocytes reabsorb IgG from the glomerular basement membrane which prevents deposition of immune complexes that might lead to glomerular diseases. This conclusion stems from the observation that FcRn-deficient mice exhibit accumulation of $\operatorname{IgG}$ in the glomerular basement membrane and delayed IgG clearance from the kidney. Excess IgG filtered by glomeruli can also be reabsorbed downstream by FcRn in the proximal tubules.

In a different study in which kidney transplants were performed between FcRn-deficient and wild-type mice, 
FcRn in the kidney was found to salvage albumin from urinary loss but promotes IgG secretion [90]. Through IgG and albumin localization, FcRn was shown to be expressed in the podocytes, the proximal tubular epithelial cells, and the vascular endothelium of the kidney. It was proposed that albumin was filtered through the glomerulus and later reabsorbed at the level of the proximal tubular epithelial cell. Similarly, it was proposed that $\operatorname{IgG}$ is reabsorbed by the podocyte and that $\mathrm{FcRn}$ within the renal vascular endothelium removes $\mathrm{IgG}$ from the circulation into the interstitium for subsequent uptake by proximal tubular epithelial cells for transcytosis back to the urine to provide immunity against infection. Both studies thus concur that FcRn within podocytes functions to reabsorb $\mathrm{IgG}$, but $\mathrm{FcRn}$ in the renal system outside of the glomeruli may be more complex in the need to balance immunity and salvage protein. Adding to the complexity, other proposed albumin-binding proteins at the proximal tubular epithelial cell-associated brush border, such as megalin and cubilin, may also be involved in albumin regulation in the urinary system [91].

\section{Expression and Function of FcRn in Liver}

FcRn expression in the liver had been demonstrated at both canalicular and sinusoidal membranes, and it is functional in IgG binding $[92,93]$. The liver is the site of albumin synthesis, and FcRn in the liver regulates albumin homeostasis [13]. Previous attempts to understand the role of FcRn function in the liver using $\beta 2 \mathrm{~m}$-deficient mice and radio-isotope-labeled IgG and albumin failed to demonstrate transcellular transport through the hepatocyte and supported a role for FcRn in the liver for the protection of IgG from catabolism [94]. Surprisingly, the same study also did not show differences in the infused serum isotopelabeled albumin levels between $\beta 2 \mathrm{~m}$-deficient and wildtype mice raising concerns over the data presented. However, this may be a result of oversaturation of the infused albumin or inadvertent structural changes caused by isotope labeling.

Other than protection from catabolism, FcRn in the liver can prevent $\operatorname{IgG}$ and albumin loss through the biliary system. Our unpublished data has shown that the bile of FcRn-deficient mice exhibits elevated levels of endogenous IgG and albumin compared to that of the wild-type counterparts. Our in vitro studies using monolayer cells grown on a transwell system have shown that FcRn can also mediate bidirectional transport of albumin across polarized epithelia (MDCK II cells) as well as basolateral recycling. This suggests that $\mathrm{FcRn}$ salvages $\mathrm{IgG}$ and albumin from loss in the bile, either through basal membrane recycling and/or transport of $\operatorname{IgG}$ and albumin from the canalicular-to-sinusoidal membrane.

\section{Expression and Function of FcRn in Brain}

FcRn expression in the brain has been found to be located within the capillary endothelium and choroid plexus epithelium using confocal microscopy [95]. FcRn, along with other immune regulated genes, is also found to be upregulated in brain tumors, such as pilocytic astrocytomas, grade II astrocytomas, and oligodendrogliomas [96]. However, the role of FcRn in these tumors is still unclear.

FcRn at the blood brain barrier (BBB) is hypothesized to mediate the efflux of $\operatorname{IgG}$ from brain to blood in a process of "reverse transcytosis". Murine models of Alzheimer's disease have shown that FcRn within the BBB is involved in the removal of amyloid beta-peptide specific $\operatorname{IgG}$ complexes from the brain of older mice, and thus plays a role in Alzheimer's disease immunotherapy [97]. However, a recent study did not find FcRn as the major factor for the low exposure of IgG in the brain [98]. Therefore, the function of FcRn in the BBB and the brain will require further investigation.

\section{Expression and Function of FcRn in Eye}

FcRn in the eye has been localized to various ocular tissues, including corneal epithelium and endothelium, lens epithelium, retinal blood vessel, conjunctiva lymphatic vessel, nonpigmented ciliary epithelium, ciliary blood vessel, iris blood vessel, and optic nerve vessel. FcRn was not detected in the retinal pigment epithelium and the choroid [99]. Murine studies of intravitreal injection of IgG suggest that ocular FcRn removes IgG across the blood-retina barrier into the systemic circulation similar to the process of reverse transcytosis described for the BBB [100]. Whether ocular FcRn is also involved in the common ophthalmic manifestations associated with various autoimmune diseases still requires investigation.

\section{Expression and Function of FcRn in Skin}

FcRn has been found to be expressed in human epidermal keratinocytes, melanocytes, hair follicles, and sebaceous glands [101, 102]. The specific function in these cells has yet to be studied. In rodent models of bullous pemphigoid, pemphigus foliaceus, and pemphigus vulgaris, the disease was ameliorated in FcRn-deficient mice or following administration of high-dose $\operatorname{IgG}$ [103]. The therapeutic effect likely reflects increased overall degradation of pathogenic IgG antibodies. Whether FcRn in the skin also directly contributes to the development of autoimmune skin blistering diseases is still unknown. 


\section{Disease Associations with FcRn}

Although animal models have shown that FcRn is involved in colitis, autoimmune skin blistering diseases, and transfer of immunity in asthma, to date, a specific human disease that is attributable to an "FcRn disorder" has yet to be found. A single report of FcRn deficiency was observed in two siblings of a consanguineous marriage who were recorded to have significantly decreased levels of $\mathrm{IgG}$ and albumin levels in the blood [104]. Using archived samples, an analysis revealed normal FcRn DNA sequence but a single nucleotide transversion at the signal sequence of the $\beta 2 \mathrm{~m}$ gene that mutated a conserved alanine to proline. The resulting $\beta 2 \mathrm{~m}$ and HLA concentration decreased to $<1 \%$ of normal. The only reported human population genetic study so far involved 404 Han Chinese subjects with and without lupus nephritis. Analysis of the variable number of tandem repeat polymorphisms within the FcRn gene promoter did not show any differences [105].

\section{Therapeutic Implications of FcRn Function}

Engineering IgG and albumin conjugates for prolonged or decreased half-life has been the cornerstone of many types of therapeutic design. The transcytosis function of FcRn in mucosal surfaces and placenta can also allow for a novel mode of drug delivery. Optimizing the interactions between $\mathrm{IgG}$ and FcRn is crucial in maximizing therapeutic efficacy while avoiding potential toxic effects.

\section{IgG-Based Therapeutics}

Recombinant therapeutics genetically engineered to contain IgG fragments with the $\mathrm{CH} 2-\mathrm{CH} 3$ domain can have significantly prolonged half-life due to protection through catabolism by FcRn binding. This also has the benefit of decreasing the frequency of administration. Methods to increase $\operatorname{IgG}$ binding to FcRn have been performed by mutating IgG at various amino acid residues: Threonine 250, Methione 252, Serine 254, Threonine 256, Threonine 307, Glutamic acid 380, Methione 428, Histidine 433, and Asparagine 434 [106]. However, increased binding affinity does not appear to be proportional to the half-life extension. For example, when comparing variants of Herceptin (ERBB2-specific human IgG1 by Genentech) antibody with a threefold increase in FcRn binding at acidic $\mathrm{pH}$ and another variant with a 12-fold increased binding at acidic $\mathrm{pH}$ and also enhanced binding at neutral $\mathrm{pH}$, both antibodies exhibited similar half-lives when tested in a humanized FcRn transgenic mouse model [107]. It has been hypothesized that increasing binding at neutral $\mathrm{pH}$ prevents $\mathrm{IgG}$ release and may instead promote degradation.

Therapeutics can also be engineered to have decreased binding wherein short half-life is desirable to avoid toxic adverse effects. For example, radiographic diagnostic imaging and toxin-conjugated products (i.e., for cancer treatment) would not require prolonged circulation in the bloodstream [108, 109].

Elimination of pathogenic antibodies in autoimmune diseases can be achieved by plasmapheresis, corticosteroid administration, or B cell depletion. An alternative method of elimination involves direct inhibition of FcRn and its interactions with $\mathrm{IgG}$ to promote catabolism of native pathogenic antibodies. This has been traditionally achieved by administration of IVIg, which is believed to compete with FcRn binding, thus resulting in accelerated degradation of endogenous pathogenic IgG antibodies left unbound to FcRn. Treatment with IVIg in murine models of myasthenia gravis, bullous pemphigoid, idiopathic thrombocytopenia, and autoimmune arthritis confirmed the benefit of increasing pathogenic IgG degradation as a means to block the immune-mediated disorder, and it appears to be independent of Fc $\gamma$ RIIb. In a similar manner, so-called "AbDeg" (antibodies that promote degradation of IgG) which are designed to bind with high affinity to FcRn have been shown to out-compete native $\operatorname{IgG}$ to allow for accelerated catabolism [107].

Other methods of interrupting FcRn and $\mathrm{IgG}$ interactions include small molecule or peptide inhibitors. Peptide inhibitors of FcRn-IgG interactions (e.g., Syntonix, SYN1436) have been found to be effective in reduction of IgG in cynomolgus monkeys by $80 \%$ without affecting the concentration of albumin [110]. Dimerization of the peptide increases the activity 200 -fold compared to that of monomers $[111,112]$. Although inhibition of $\beta 2 \mathrm{~m}$ function with specific antibody can also reduce FcRn function, there may be unwanted side effects of inhibiting other $\beta 2 \mathrm{~m}$-associated molecules, such as MHC class I, CD1, and HFE [113].

Since FcRn is known to transport IgG across mucosal epithelia, Fc-conjugated therapeutics have been shown to reach the circulation from the lumen via transcytosis across the intestinal or pulmonary mucosa. Various proteins, such as erythropoietin (Epo), follicle-stimulating hormone, interferon-alpha and -beta, have been conjugated to the Fc region of human IgG1 to facilitate such drug delivery upon inhalation through the upper airway where FcRn resides in humans and non-human primates [81]. Fc fusion "monomers", which consist of Fc dimers with a monomeric therapeutic protein that replaces the Fab region, are found to have improved transport efficiency and longer half-life than Fc fusion dimers [81]. Fc fusion proteins of molecular weight $\geq 100 \mathrm{kDa}$ can be administered in liquid aerosols wherein they are able to cross the pulmonary epithelium by 
transcytosis within the upper/central airways to reach the circulation in an FcRn-dependent pathway [79]. When examined using an Epo-Fc monomer, the inhalation route results in $30-60 \%$ bioavailability in non-human primates, which is similar to that of subcutaneous injection of the standard erythropoietin protein.

Published studies have used newborn rats to demonstrate intestinal transport of FSH-Fc fusion proteins together with a long half-life of circulation that approaches approximately

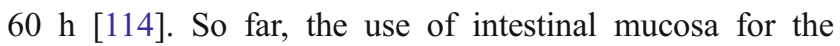
transport of $\mathrm{Fc}$ fusion proteins has yet to be rigorously investigated.

Given the utility of such IgG-based therapeutics, simpler strategies have been sought for the generation of such fusion proteins. The development of cows that contain a human IgG transgene to produce human IgG suggests that such strategies can represent an alternative way to create large quantities of Fc-based therapeutics protein generation [23].

\section{Albumin-Based Therapeutics}

The use of albumin to extend the half-life of therapeutic proteins began prior to the knowledge that $\mathrm{FcRn}$ is critical to albumin homeostasis. Three decades ago, chemical conjugation of "high molecular weight carriers", such as albumin to methotrexate was found to be effective in halflife extension, for example [115]. The clinical efficacy of albumin-methotrexate in subsequent treatment of renal carcinomas and rheumatoid arthritis was also attributed to the increased uptake of albumin as an energy source in the setting of inflammation and malignancy $[116,117]$.

Recombinant technology has now allowed for fusion of albumin to either the carboxy or amino terminus of a therapeutic protein of interest. Some examples include interferon-alpha $2 \mathrm{~b}$ (Albinterferon), granulocyte colony stimulating factor (Albugranin), growth hormone (Albutropin), insulin (albudin), CD4, hirudin, and IgG fragments themselves [118]. Albinterferon (used for the treatment of chronic hepatitis C), for example, can be administered less frequently and with similar clinical efficacy as interferon conjugated to polyethylene glycol [119]. Since both FcRn and hepatitis $\mathrm{C}$ virus resides in the hepatocyte, it is unknown whether albumin conjugation also provides the additional benefit of targeting the liver. Furthermore, it is unknown whether its potential side effects may be also be related to FcRn expression in other organs such as the lung.

Albumin-based nanoparticles, such as Abrexane (albuminencapsulated Paclitaxel), used for the treatment of metastatic breast cancer, were developed as a delivery vehicle to avoid chemical solvents like Cremophor. It is unknown how this interacts with $\mathrm{FcRn}$ and whether the side effects are associated with FcRn biology.
Other recent novel therapeutic designs have used indirect methods to bind to albumin. Insulin detemir (Levemir, Novo Nordisk) is an insulin analogue with a lysine residue bound to a fatty acid (myristic acid) which will bind to albumin in blood and later dissociate from the complex. Drug Affinity Complex (DACTM) is a design that couples medications to a maleimide group, which will bind specifically and irreversible to albumin [120]. The albumin-binding domain from Streptococcus strain G148 protein G has also been fused to a divalent anti-HER 2 affibody and anti-CEA single-chain diabodies to extend half-life [121, 122].

\section{Conclusion}

Our understanding of antibody transport and immunity has expanded dramatically since the experimental era of Brambell subsequent to the cloning and crystallographic resolution of FcRn structure and the generation of experimental tools such as Fc-deficient mice. We have clarified the observations and predictions made by Brambell decades ago. As summarized in this review, these insights have lead and are rapidly leading to variety of enhanced therapeutics and therapeutic approaches which co-opt these new biological principles.

Acknowledgements The authors have had research support over the years from National Institute of Health DK071798, DK053056, DK034854, American Liver Foundation, and Crohn's and Colitis Foundation.

Open Access This article is distributed under the terms of the Creative Commons Attribution Noncommercial License which permits any noncommercial use, distribution, and reproduction in any medium, provided the original author(s) and source are credited.

\section{References}

1. Brambell FW. The transmission of immune globulins from the mother to the foetal and newborn young. Proc Nutr Soc. 1969;28 (1):35-41.

2. Brambell FW, Hemmings WA, Morris IG. A theoretical model of gamma-globulin catabolism. Nature. 1964;203:1352-4.

3. Rodewald R. pH-dependent binding of immunoglobulins to intestinal cells of the neonatal rat. J Cell Biol. 1976;71(2):666-9.

4. Simister NE, Mostov KE. An Fc receptor structurally related to MHC class I antigens. Nature. 1989;337(6203):184-7.

5. Raghavan M, Gastinel LN, Bjorkman PJ. The class I major histocompatibility complex related $\mathrm{Fc}$ receptor shows $\mathrm{pH}$ dependent stability differences correlating with immunoglobulin binding and release. Biochemistry. 1993;32(33):8654-60.

6. Huber AH, Kelley RF, Gastinel LN, Bjorkman PJ. Crystallization and stoichiometry of binding of a complex between a rat intestinal Fc receptor and Fc. J Mol Biol. 1993;230(3):1077-83.

7. Raghavan M, Chen MY, Gastinel LN, Bjorkman PJ. Investigation of the interaction between the class I MHC-related Fc receptor and its immunoglobulin G ligand. Immunity. 1994;1 (4):303-15. 
8. Vaughn DE, Milburn CM, Penny DM, Martin WL, Johnson JL, Bjorkman PJ. Identification of critical IgG binding epitopes on the neonatal Fc receptor. J Mol Biol. 1997;274(4):597-607.

9. Raghavan M, Bonagura VR, Morrison SL, Bjorkman PJ. Analysis of the $\mathrm{pH}$ dependence of the neonatal Fc receptor/ immunoglobulin $\mathrm{G}$ interaction using antibody and receptor variants. Biochemistry. 1995;34(45):14649-57.

10. Medesan C, Matesoi D, Radu C, Ghetie V, Ward ES. Delineation of the amino acid residues involved in transcytosis and catabolism of mouse IgG1. J Immunol. 1997;158(5):2211-7.

11. Chaudhury C, Mehnaz S, Robinson JM, Hayton WL, Pearl DK, Roopenian DC, et al. The major histocompatibility complexrelated $\mathrm{Fc}$ receptor for $\mathrm{IgG}(\mathrm{FcRn})$ binds albumin and prolongs its lifespan. J Exp Med. 2003;197(3):315-22.

12. Schultze HE, Heremans JF. Molecular biology of human proteins: with special reference to plasma proteins. New York: Elsevier; 1966.

13. Kim J, Bronson CL, Hayton WL, Radmacher MD, Roopenian DC, Robinson JM, et al. Albumin turnover: FcRn-mediated recycling saves as much albumin from degradation as the liver produces. Am J Physiol Gastrointest Liver Physiol. 2005;290(2): G352-60.

14. Andersen JT, Dee Qian J, Sandlie I. The conserved histidine 166 residue of the human neonatal $\mathrm{Fc}$ receptor heavy chain is critical for the $\mathrm{pH}$-dependent binding to albumin. Eur $\mathrm{J}$ Immunol. 2006;36(11):3044-51.

15. Chaudhury C, Brooks CL, Carter DC, Robinson JM, Anderson CL. Albumin binding to FcRn: distinct from the FcRn-IgG interaction. Biochemistry. 2006;45(15):4983-90.

16. Roopenian DC, Christianson GJ, Sproule TJ, et al. The MHC class I-like IgG receptor controls perinatal IgG transport, IgG homeostasis, and fate of $\mathrm{IgG}-\mathrm{Fc}-$ coupled drugs. J Immunol. 2003;170(7):3528-33.

17. Vaughn DE, Bjorkman PJ. Structural basis of pH-dependent antibody binding by the neonatal Fc receptor. Structure. 1998;6 (1):63-73.

18. Ober RJ, Radu CG, Ghetie V, Ward ES. Differences in promiscuity for antibody-FcRn interactions across species: implications for therapeutic antibodies. Int Immunol. 2001;13 (12):1551-9.

19. Zhou J, Johnson JE, Ghetie V, Ober RJ, Ward ES. Generation of mutated variants of the human form of the MHC class I-related receptor, FcRn, with increased affinity for mouse immunoglobulin G. J Mol Biol. 2003;332(4):901-13.

20. Kuo TT, de Muinck EJ, Claypool SM, Yoshida M, Nagaishi T, Aveson $\mathrm{VG}$, et al. $\mathrm{N}$-glycan moieties in neonatal $\mathrm{Fc}$ receptor determine steady-state membrane distribution and directional transport of IgG. J Biol Chem. 2009;284(13):8292-300.

21. Andersen JT, Daba MB, Berntzen G, Michaelsen TE, Sandlie I. Cross-species binding analyses of mouse and human neonatal $\mathrm{Fc}$ receptor show dramatic differences in immunoglobulin $\mathrm{G}$ and albumin binding. J Biol Chem. 2010;285(7):4826-36.

22. Smith BJ, Popplewell A, Athwal D, et al. Prolonged in vivo residence times of antibody fragments associated with albumin. Bioconjug Chem. 2001;12(5):750-6.

23. Kacskovics I. Fc receptors in livestock species. Vet Immunol Immunopathol. 2004;102(4):351-62.

24. Lu W, Zhao Z, Zhao Y, et al. Over-expression of the bovine $\mathrm{FcRn}$ in the mammary gland results in increased IgG levels in both milk and serum of transgenic mice. Immunology. 2007;122 (3):401-8.

25. Zhu X, Peng J, Raychowdhury R, Nakajima A, Lencer WI, Blumberg RS. The heavy chain of neonatal Fc receptor for IgG is sequestered in endoplasmic reticulum by forming oligomers in the absence of beta2-microglobulin association. Biochem $\mathrm{J}$. 2002;367(Pt 3):703-14.
26. Claypool SM, Dickinson BL, Yoshida M, Lencer WI, Blumberg RS. Functional reconstitution of human FcRn in Madin-Darby canine kidney cells requires co-expressed human beta 2microglobulin. J Biol Chem. 2002;277(31):28038-50.

27. Zhu X, Peng J, Chen D, et al. Calnexin and ERp57 facilitate the assembly of the neonatal $\mathrm{Fc}$ receptor for IgG with beta 2microglobulin in the endoplasmic reticulum. J Immunol. 2005;175(2):967-76.

28. Dickinson BL, Badizadegan $\mathrm{K}, \mathrm{Wu} \mathrm{Z}$, Ahouse JC, Zhu X, Simister NE, et al. Bidirectional FcRn-dependent IgG transport in a polarized human intestinal epithelial cell line. J Clin Invest. 1999;104(7):903-11.

29. Ellinger I, Rothe A, Grill M, Fuchs R. Apical to basolateral transcytosis and apical recycling of immunoglobulin $G$ in trophoblast-derived BeWo cells: effects of low temperature, nocodazole, and cytochalasin D. Exp Cell Res. 2001;269 (2):322-31.

30. Radulescu L, Antohe F, Jinga V, Ghetie V, Simionescu M. Neonatal Fc receptors discriminates and monitors the pathway of native and modified immunoglobulin $\mathrm{G}$ in placental endothelial cells. Hum Immunol. 2004;65(6):578-85.

31. Kim KJ, Fandy TE, Lee VH, Ann DK, Borok Z, Crandall ED. Net absorption of IgG via FcRn-mediated transcytosis across rat alveolar epithelial cell monolayers. Am J Physiol Lung Cell Mol Physiol. 2004;287(3):L616-22.

32. Tzaban S, Massol RH, Yen E, et al. The recycling and transcytotic pathways for $\mathrm{IgG}$ transport by $\mathrm{FcRn}$ are distinct and display an inherent polarity. J Cell Biol. 2009;185(4):67384

33. Ward ES, Martinez C, Vaccaro C, Zhou J, Tang Q, Ober RJ. From sorting endosomes to exocytosis: association of Rab4 and Rab11 GTPases with the Fc receptor, FcRn, during recycling. Mol Biol Cell. 2005;16(4):2028-38.

34. He W, Ladinsky MS, Huey-Tubman KE, Jensen GJ, McIntosh JR, Bjorkman PJ. FcRn-mediated antibody transport across epithelial cells revealed by electron tomography. Nature. 2008;455(7212):542-6.

35. Claypool SM, Dickinson BL, Wagner JS, Johansen FE, Venu N, Borawski JA, et al. Bidirectional transepithelial IgG transport by a strongly polarized basolateral membrane Fcgamma-receptor. Mol Biol Cell. 2004;15(4):1746-59.

36. Dickinson BL, Claypool SM, D'Angelo JA, et al. Ca2+dependent calmodulin binding to FcRn affects immunoglobulin G transport in the transcytotic pathway. Mol Biol Cell. 2008;19 (1):414-23

37. McCarthy KM, Lam M, Subramanian L, Shakya R, Wu Z, Newton $\mathrm{EE}$, et al. Effects of mutations in potential phosphorylation sites on transcytosis of FcRn. J Cell Sci. 2001;114(Pt 8):1591-8.

38. Wu Z, Simister NE. Tryptophan- and dileucine-based endocytosis signals in the neonatal Fc receptor. J Biol Chem. 2001;276 (7):5240-7.

39. Stefaner I, Praetor A, Hunziker W. Nonvectorial surface transport, endocytosis via a Di-leucine-based motif, and bidirectional transcytosis of chimera encoding the cytosolic tail of rat FcRn expressed in Madin-Darby canine kidney cells. J Biol Chem. 1999;274(13):8998-9005.

40. Qiao SW, Kobayashi K, Johansen FE, et al. Dependence of antibody-mediated presentation of antigen on FcRn. Proc Natl Acad Sci USA. 2008;105(27):9337-42.

41. Zhu X, Meng G, Dickinson BL, et al. MHC class I-related neonatal $\mathrm{Fc}$ receptor for $\mathrm{IgG}$ is functionally expressed in monocytes, intestinal macrophages, and dendritic cells. J Immunol. 2001;166(5):3266-76.

42. Tesar DB, Tiangco NE, Bjorkman PJ. Ligand valency affects transcytosis, recycling and intracellular trafficking mediated by the neonatal Fc receptor. Traffic. 2006;7(9):1127-42. 
43. Tiwari B, Junghans RP. Functional analysis of the mouse Fcgrt 5' proximal promoter. Biochim Biophys Acta. 2005;1681(2-3): 88-98.

44. Liu X, Ye L, Christianson GJ, Yang JQ, Roopenian DC, Zhu X. NF-kappaB signaling regulates functional expression of the MHC class I-related neonatal $\mathrm{Fc}$ receptor for IgG via intronic binding sequences. J Immunol. 2007;179(5):2999-3011.

45. Liu X, Ye L, Bai Y, Mojidi H, Simister NE, Zhu X. Activation of the JAK/STAT-1 signaling pathway by IFN-gamma can downregulate functional expression of the MHC class I-related neonatal Fc receptor for IgG. J Immunol. 2008;181(1):449-63.

46. Gill RK, Mahmood S, Sodhi CP, Nagpaul JP, Mahmood A. IgG binding and expression of its receptor in rat intestine during postnatal development. Indian J Biochem Biophys. 1999;36(4):252-7.

47. Capano G, Bloch KJ, Schiffrin EJ, Dascoli JA, Israel EJ, Harmatz PR. Influence of the polyamine, spermidine, on intestinal maturation and dietary antigen uptake in the neonatal rat. J Pediatr Gastroenterol Nutr. 1994;19(1):34-42.

48. Verdin-Teran SL, Vilches-Flores A, Moreno-Fierros L. Immunization with Cry1Ac from Bacillus thuringiensis increases intestinal $\mathrm{IgG}$ response and induces the expression of FcRn in the intestinal epithelium of adult mice. Scand J Immunol. 2009;70(6):596-607.

49. Shah U, Dickinson BL, Blumberg RS, Simister NE, Lencer WI, Walker WA. Distribution of the IgG Fc receptor, FcRn, in the human fetal intestine. Pediatr Res. 2003;53(2):295-301.

50. Israel EJ, Taylor S, Wu Z, Mizoguchi E, Blumberg RS, Bhan A, et al. Expression of the neonatal Fc receptor, FcRn, on human intestinal epithelial cells. Immunology. 1997;92(1):69-74.

51. Yoshida M, Claypool SM, Wagner JS, Mizoguchi E, Mizoguchi A, Roopenian DC, et al. Human neonatal Fc receptor mediates transport of $\mathrm{IgG}$ into luminal secretions for delivery of antigens to mucosal dendritic cells. Immunity. 2004;20(6):769-83.

52. Yoshida M, Kobayashi K, Kuo TT, et al. Neonatal Fc receptor for IgG regulates mucosal immune responses to luminal bacteria. J Clin Invest. 2006;116(8):2142-51.

53. Bry L, Brenner MB. Critical role of $\mathrm{T}$ cell-dependent serum antibody, but not the gut-associated lymphoid tissue, for surviving acute mucosal infection with Citrobacter rodentium, an attaching and effacing pathogen. J Immunol. 2004;172(1):433-41.

54. Kobayashi K, Qiao SW, Yoshida M, Baker K, Lencer WI, Blumberg RS. An FcRn-dependent role for anti-flagellin immunoglobulin $\mathrm{G}$ in pathogenesis of colitis in mice. Gastroenterology. 2009;137(5):1746.e1-56.e1.

55. Hine BC, Hunt PW, Beasley AM, Windon RG, Glover SA, Colditz IG. Selective transport of IgE into ovine mammary secretions. Res Vet Sci. 2010;89(2):184-90.

56. Cianga P, Cianga C, Cozma L, Ward ES, Carasevici E. The MHC class I related Fc receptor, FcRn, is expressed in the epithelial cells of the human mammary gland. Hum Immunol. 2003;64(12):1152-9.

57. Kacskovics I, Mayer B, Kis Z, Frenyo LV, Zhao Y, Muyldermans $\mathrm{S}$, et al. Cloning and characterization of the dromedary (Camelus dromedarius) neonatal $\mathrm{Fc}$ receptor $(\mathrm{drFcRn})$. Dev Comp Immunol. 2006;30(12):1203-15.

58. Sayed-Ahmed A, Kassab M, Abd-Elmaksoud A, Elnasharty M, El-Kirdasy A. Expression and immunohistochemical localization of the neonatal $\mathrm{Fc}$ receptor $(\mathrm{FcRn})$ in the mammary glands of the Egyptian water buffalo. Acta Histochem. 2010;112(4):383-91.

59. Israel EJ, Patel VK, Taylor SF, Marshak-Rothstein A, Simister NE. Requirement for a beta 2-microglobulin-associated Fc receptor for acquisition of maternal $\mathrm{IgG}$ by fetal and neonatal mice. J Immunol. 1995;154(12):6246-51.

60. Cianga P, Medesan C, Richardson JA, Ghetie V, Ward ES. Identification and function of neonatal $\mathrm{Fc}$ receptor in mammary gland of lactating mice. Eur J Immunol. 1999;29(8):2515-23.
61. Adamski FM, King AT, Demmer J. Expression of the Fc receptor in the mammary gland during lactation in the marsupial Trichosurus vulpecula (brushtail possum). Mol Immunol. 2000;37(8):435-44.

62. Mayer B, Zolnai A, Frenyo LV, Jancsik V, Szentirmay Z, Hammarstrom L, et al. Localization of the sheep FcRn in the mammary gland. Vet Immunol Immunopathol. 2002;87(3-4): 327-30.

63. Mayer B, Doleschall M, Bender B, Bartyik J, Bosze Z, Frenyo $\mathrm{LV}$, et al. Expression of the neonatal $\mathrm{Fc}$ receptor $(\mathrm{FcRn})$ in the bovine mammary gland. J Dairy Res. 2005;72:107-12.

64. Polte T, Hennig C, Hansen G. Allergy prevention starts before conception: maternofetal transfer of tolerance protects against the development of asthma. J Allergy Clin Immunol. 2008;122 (5):1022.e5-30.e5.

65. Nakata K, Kobayashi K, Ishikawa Y, et al. The transfer of maternal antigen-specific $\mathrm{IgG}$ regulates the development of allergic airway inflammation early in life in an FcRn-dependent manner. Biochem Biophys Res Commun. 2010;395(2):238-43.

66. Matson AP, Thrall RS, Rafti E, Lingenheld EG, Puddington L. IgG transmitted from allergic mothers decreases allergic sensitization in breastfed offspring. Clin Mol Allergy. 2010;8:9. doi:10.1186/1476-7961-8-9.

67. Pentsuk N, van der Laan JW. An interspecies comparison of placental antibody transfer: new insights into developmental toxicity testing of monoclonal antibodies. Birth Defects Res B Dev Reprod Toxicol. 2009;86(4):328-44.

68. Simister NE. Placental transport of immunoglobulin G. Vaccine. 2003;21(24):3365-9.

69. Kim J, Mohanty S, Ganesan LP, Hua K, Jarjoura D, Hayton WL, et al. FcRn in the yolk sac endoderm of mouse is required for IgG transport to fetus. J Immunol. 2009;182(5):2583-9.

70. Antohe F, Radulescu L, Gafencu A, Ghetie V, Simionescu M. Expression of functionally active FcRn and the differentiated bidirectional transport of IgG in human placental endothelial cells. Hum Immunol. 2001;62(2):93-105.

71. Mohanty S, Kim J, Ganesan LP, et al. IgG is transported across the mouse yolk sac independently of FcgammaRIIb. J Reprod Immunol. 2010;84(2):133-44.

72. Grubb JH, Vogler C, Tan Y, Shah GN, MacRae AF, Sly WS. Infused Fc-tagged beta-glucuronidase crosses the placenta and produces clearance of storage in utero in mucopolysaccharidosis VII mice. Proc Natl Acad Sci USA. 2008;105(24):8375-80.

73. Chen P, Li C, Lang S, Zhu G, Reheman A, Spring CM, Freedman J, Ni H. Animal model of fetal and neonatal immune thrombocytopenia: role of neonatal $\mathrm{Fc}$ receptor in the pathogenesis and therapy. Blood 2010 (in press)

74. Kolonin MG, Pasqualini R, Arap W. Teratogenicity induced by targeting a placental immunoglobulin transporter. Proc Natl Acad Sci USA. 2002;99(20):13055-60.

75. Spiekermann GM, Finn PW, Ward ES, Dumont J, Dickinson BL, Blumberg RS, et al. Receptor-mediated immunoglobulin G transport across mucosal barriers in adult life: functional expression of FcRn in the mammalian lung. J Exp Med. 2002;196(3):303-10.

76. Hand WL, Cantey JR. Antibacterial mechanisms of the lower respiratory tract. I. Immunoglobulin synthesis and secretion. J Clin Invest. 1974;53(2):354-62.

77. Sakagami M, Omidi Y, Campbell L, Kandalaft LE, Morris CJ, Barar J, et al. Expression and transport functionality of FcRn within rat alveolar epithelium: a study in primary cell culture and in the isolated perfused lung. Pharm Res. 2006;23(2):270-9.

78. Mayer B, Kis Z, Kajan G, Frenyo LV, Hammarstrom L, Kacskovics I. The neonatal Fc receptor (FcRn) is expressed in the bovine lung. Vet Immunol Immunopathol. 2004;98(1-2): $85-9$. 
79. Bitonti AJ, Dumont JA. Pulmonary administration of therapeutic proteins using an immunoglobulin transport pathway. Adv Drug Deliv Rev. 2006;58(9-10):1106-18.

80. Dumont JA, Bitonti AJ, Clark D, Evans S, Pickford M, Newman SP. Delivery of an erythropoietin-Fc fusion protein by inhalation in humans through an immunoglobulin transport pathway. J Aerosol Med. 2005;18(3):294-303.

81. Dumont JA, Low SC, Peters RT, Bitonti AJ. Monomeric Fc fusions: impact on pharmacokinetic and biological activity of protein therapeutics. BioDrugs. 2006;20(3):151-60.

82. Montoyo HP, Vaccaro C, Hafner M, Ober RJ, Mueller W, Ward ES. Conditional deletion of the MHC class I-related receptor FcRn reveals the sites of IgG homeostasis in mice. Proc Natl Acad Sci USA. 2009;106(8):2788-93.

83. Akilesh S, Christianson GJ, Roopenian DC, Shaw AS. Neonatal $\mathrm{FcR}$ expression in bone marrow-derived cells functions to protect serum $\mathrm{IgG}$ from catabolism. J Immunol. 2007;179 (7):4580-8.

84. Baker K, Qiao SW, Kuo T, Kobayashi K, Yoshida M, Lencer WI, et al. Immune and non-immune functions of the (not so) neonatal $\mathrm{Fc}$ receptor, FcRn. Semin Immunopathol. 2009;31(2):223-36.

85. Ochi $\mathrm{H}$, Abraham $\mathrm{M}$, Ishikawa $\mathrm{H}$, et al. New immunosuppressive approaches: oral administration of $\mathrm{CD} 3$-specific antibody to treat autoimmunity. J Neurol Sci. 2008;274(1-2):9-12.

86. Vidarsson G, Stemerding AM, Stapleton NM, Spliethoff SE, Janssen H, Rebers FE, et al. FcRn: an IgG receptor on phagocytes with a novel role in phagocytosis. Blood. 2006;108 (10):3573-9.

87. Kobayashi N, Suzuki Y, Tsuge T, Okumura K, Ra C, Tomino Y. FcRn-mediated transcytosis of immunoglobulin $G$ in human renal proximal tubular epithelial cells. Am J Physiol Renal Physiol. 2002;282(2):F358-65.

88. Akilesh S, Huber TB, Wu H, et al. Podocytes use FcRn to clear IgG from the glomerular basement membrane. Proc Natl Acad Sci USA. 2008;105(3):967-72.

89. Haymann JP, Levraud JP, Bouet S, et al. Characterization and localization of the neonatal $\mathrm{Fc}$ receptor in adult human kidney. J Am Soc Nephrol. 2000;11(4):632-9.

90. Sarav M, Wang Y, Hack BK, Chang A, Jensen M, Bao L, et al. Renal FcRn reclaims albumin but facilitates elimination of IgG. J Am Soc Nephrol. 2009;20(9):1941-52.

91. Birn H, Christensen EI. Renal albumin absorption in physiology and pathology. Kidney Int. 2006;69(3):440-9.

92. Blumberg RS, Koss T, Story CM, et al. A major histocompatibility complex class I-related $\mathrm{Fc}$ receptor for $\operatorname{IgG}$ on rat hepatocytes. J Clin Invest. 1995;95(5):2397-402.

93. Borvak J, Richardson J, Medesan C, Antohe F, Radu C, Simionescu M, et al. Functional expression of the MHC class I-related receptor, FcRn, in endothelial cells of mice. Int Immunol. 1998;10(9):1289-98.

94. Telleman P, Junghans RP. The role of the Brambell receptor (FcRB) in liver: protection of endocytosed immunoglobulin $\mathrm{G}$ $(\mathrm{IgG})$ from catabolism in hepatocytes rather than transport of $\mathrm{IgG}$ to bile. Immunology. 2000;100(2):245-51.

95. Schlachetzki F, Zhu C, Pardridge WM. Expression of the neonatal $\mathrm{Fc}$ receptor $(\mathrm{FcRn})$ at the blood-brain barrier. J Neurochem. 2002;81(1):203-6.

96. Huang H, Hara A, Homma T, Yonekawa Y, Ohgaki H. Altered expression of immune defense genes in pilocytic astrocytomas. $\mathrm{J}$ Neuropathol Exp Neurol. 2005;64(10):891-901.

97. Deane R, Sagare A, Hamm K, et al. IgG-assisted age-dependent clearance of Alzheimer's amyloid beta peptide by the bloodbrain barrier neonatal Fc receptor. J Neurosci. 2005;25 (50):11495-503.

98. Garg A, Balthasar JP. Investigation of the influence of FcRn on the distribution of IgG to the brain. AAPS J. 2009;11(3):553-7.
99. Kim H, Fariss RN, Zhang C, Robinson SB, Thill M, Csaky KG. Mapping of the neonatal $\mathrm{Fc}$ receptor in the rodent eye. Invest Ophthalmol Vis Sci. 2008;49(5):2025-9.

100. Kim H, Robinson SB, Csaky KG. FcRn receptor-mediated pharmacokinetics of therapeutic $\mathrm{IgG}$ in the eye. Mol Vis. 2009; 15:2803-12.

101. Cauza K, Hinterhuber G, Dingelmaier-Hovorka R, Brugger K, Klosner G, Horvat R, et al. Expression of FcRn, the MHC class I-related receptor for IgG, in human keratinocytes. J Invest Dermatol. 2005;124(1):132-9.

102. Cianga P, Cianga C, Plamadeala P, Branisteanu D, Carasevici E. The neonatal $\mathrm{Fc}$ receptor $(\mathrm{FcRn})$ expression in the human skin. Virchows Arch. 2007;451(4):859-60.

103. Li N, Zhao M, Hilario-Vargas J, Prisayanh P, Warren S, Diaz LA, et al. Complete FcRn dependence for intravenous Ig therapy in autoimmune skin blistering diseases. J Clin Invest. 2005;115 (12):3440-50

104. Wani MA, Haynes LD, Kim J, et al. Familial hypercatabolic hypoproteinemia caused by deficiency of the neonatal $\mathrm{Fc}$ receptor, FcRn, due to a mutant beta2-microglobulin gene. Proc Natl Acad Sci USA. 2006;103(13):5084-9.

105. Zhou XJ, Yu L, Zhu L, Hou P, Lv JC, Yu F, et al. Association between polymorphisms in the FCGRT gene and lupus nephritis in Chinese patients. Clin Exp Rheumatol. 2009;27(4):609-14.

106. Roopenian DC, Akilesh S. FcRn: the neonatal Fc receptor comes of age. Nat Rev Immunol. 2007;7(9):715-25.

107. Petkova SB, Akilesh S, Sproule TJ, et al. Enhanced half-life of genetically engineered human IgG1 antibodies in a humanized FcRn mouse model: potential application in humorally mediated autoimmune disease. Int Immunol. 2006; 18(12):1759-69.

108. Stern M, Herrmann R. Overview of monoclonal antibodies in cancer therapy: present and promise. Crit Rev Oncol Hematol. 2005;54(1):11-29.

109. Kenanova V, Olafsen T, Crow DM, et al. Tailoring the pharmacokinetics and positron emission tomography imaging properties of anti-carcinoembryonic antigen single-chain $\mathrm{Fv}-\mathrm{Fc}$ antibody fragments. Cancer Res. 2005;65(2):622-31.

110. Mezo AR, McDonnell KA, Hehir CA, et al. Reduction of IgG in nonhuman primates by a peptide antagonist of the neonatal $\mathrm{Fc}$ receptor FcRn. Proc Natl Acad Sci USA. 2008;105(7): 2337-42.

111. McDonnell KA, Low SC, Hoehn T, Donnelly R, Palmieri H, Fraley C, et al. Synthesis and structure-activity relationships of dimeric peptide antagonists of the human immunoglobulin Ghuman neonatal $\mathrm{Fc}$ receptor (IgG-FcRn) interaction. J Med Chem. 2010;53(4):1587-96.

112. Mezo AR, Sridhar V, Badger J, Sakorafas P, Nienaber V. X-ray crystal structures of monomeric and dimeric peptide inhibitors in complex with the human neonatal Fc receptor, FcRn. J Biol Chem. 2010;285(36):27694-701.

113. Getman KE, Balthasar JP. Pharmacokinetic effects of 4C9, an anti-FcRn antibody, in rats: implications for the use of FcRn inhibitors for the treatment of humoral autoimmune and alloimmune conditions. J Pharm Sci. 2005;94(4):718-29.

114. Low SC, Nunes SL, Bitonti AJ, Dumont JA. Oral and pulmonary delivery of $\mathrm{FSH}-\mathrm{Fc}$ fusion proteins via neonatal Fc receptor-mediated transcytosis. Hum Reprod. 2005;20(7): 1805-13.

115. Chu BC, Whiteley JM. High molecular weight derivatives of methotrexate as chemotherapeutic agents. Mol Pharmacol. 1977;13(1):80-8

116. Vis AN, van der Gaast A, van Rhijn BW, Catsburg TK, Schmidt C, Mickisch GH. A phase II trial of methotrexate-human serum albumin (MTX-HSA) in patients with metastatic renal cell carcinoma who progressed under immunotherapy. Cancer Chemother Pharmacol. 2002;49(4):342-5. 
117. Wunder A, Muller-Ladner U, Stelzer EH, et al. Albumin-based drug delivery as novel therapeutic approach for rheumatoid arthritis. J Immunol. 2003;170(9):4793-801.

118. Andersen JT, Sandlie I. The versatile MHC class I-related FcRn protects $\operatorname{IgG}$ and albumin from degradation: implications for development of new diagnostics and therapeutics. Drug Metab Pharmacokinet. 2009;24(4):318-32.

119. Zeuzem S, Yoshida EM, Benhamou Y, et al. Albinterferon alfa-2b dosed every two or four weeks in interferon-naive patients with genotype 1 chronic hepatitis C. Hepatology. 2008;48(2):407-17.
120. Giannoukakis N. CJC-1131. ConjuChem Curr Opin Investig Drugs. 2003;4(10):1245-9.

121. Tolmachev V, Orlova A, Pehrson R, et al. Radionuclide therapy of HER2-positive microxenografts using a 177Lu-labeled HER2specific affibody molecule. Cancer Res. 2007;67(6):2773-82.

122. Stork R, Muller D, Kontermann RE. A novel tri-functional antibody fusion protein with improved pharmacokinetic properties generated by fusing a bispecific single-chain diabody with an albumin-binding domain from streptococcal protein G. Protein Eng Des Sel. 2007;20(11):569-76. 